\author{
EMILIA SZYMCZAK \\ Uniwersytet im. Adama Mickiewicza \\ $w$ Poznaniu
}

\title{
PROMOCJE DOKTORSKIE JAKO CEREMONIE AKADEMICKIE
}

\begin{abstract}
Szymczak Emilia, Promocje doktorskie jako ceremonie akademickie [Doctoral Promotions as Academic Ceremonies]. Studia Edukacyjne nr 48, 2018, Poznań 2018, pp. 215-227. Adam Mickiewicz University Press. ISSN 1233-6688. DOI: 10.14746/se.2018.48.14

Academic regalia, symbols and ceremonies are an important element of university reality. The ruling force here is the tradition and continuity of the preservation of symbols since the Middle Ages. The awarding of academic degrees and titles in the XXI century is still associated with a consistent structure during which specific rituals - characteristic for University or even each field of study - take place. They become an exemplification of prestige in the academic world, the position of professors, as well as other social groups, and crystallize the place in the hierarchy of various individuals and groups of people, as well as the academic capital that they represent. In this article, I will focus on this initial level of academic career which is a doctorate and especially at this ceremonial or symbolic ritual of passage - the doctoral promotion.
\end{abstract}

Key words: academy, ceremony, regalia, cereer, degree, doctoral studies

Żyjemy w świecie symboli i prestiżu, w świecie walki o miejsce w strukturze społecznej. Może być ona definiowana za pomocą różnych zmiennych, takich jak wykształcenie, dochód, zawód, czy stanowisko. W świecie nauki i uniwersytetu na szczycie hierarchii stoją profesorowie uosabiający z jednej strony mądrość, z drugiej - karierę akademicką w najlepszym tego słowa wymiarze. Wyrazem prestiżu w świecie akademickim, pozycji profesorów, jak również innych grup społecznych są różnorodne rytuały przejścia i symbole, które krystalizują zarówno miejsce w hierarchii różnych jednostek i grup ludzi, jak i kapitał naukowy czy akademicki, który reprezentują. Nieprzypadkowo przecież $\mathrm{w}$ Polsce nominacje na profesora tytularnego podpisuje prezydent i to przez niego oraz $\mathrm{w}$ jego pałacu wręczane są te dyplomy. W moim 
artykule skoncentruję się na tym początkowym szczeblu kariery akademickiej, jakim jest doktorat, a szczególnie na tym ceremoniale czy symbolicznym rytuale przejścia, jakim jest promocja doktorska.

Przyjmuje się, iż początki stopnia doktora sięgają czasów średniowiecznych. Wtedy to termin ten odnosił się do osoby, która miała kwalifikacje do nauczania łaciny na uniwersytecie ${ }^{1}$. Termin "doktor" używany był też w odniesieniu do przedstawicieli kościoła chrześcijańskiego, przewodników duchowych, autorytetów religijnych, którzy interpretowali Biblię i nauczali innych ${ }^{2}$. Warto przy tym wspomnieć, iż pierwotnie prawo do nadawania tego tytułu mieli przedstawiciele Kościoła katolickiego, a proces przyznawania licenentia docendi wymagał od kandydatów spełnienia trzech warunków: pomyślnego zaliczenia testu wiedzy, złożenia przysięgi wierności oraz uiszczenia stosownej opłaty. Sami kandydaci podlegali selekcji - były to osoby utalentowane, zdolne, o odpowiednim poziomie umiejętności i wiedzy ${ }^{3}$. Termin doktor pochodzi od łacińskiego słowa docere oznaczającego "uczyć" i początkowo odnosił się do nauczyciela lub instruktora. Obecnie niniejszy tytuł nadawany jest przez uczelnie niemal na całym świecie i stanowi potwierdzenie zdobytej wiedzy, posiadanych umiejętności oraz kwalifikacji umożliwiających nauczanie na poziomie uniwersyteckim w ramach określonej dziedziny studiów. Wyróżniamy bowiem kilka rodzajów doktoratów, jak na przykład naukowe lub wdrożeniowe. Najczęściej spotykany i najbardziej tradycyjny jest jednak Doctor of Philosophy (PhD) ${ }^{4}$ przyznawany w wielu dziedzinach - zarówno w naukach humanistycznych, jak i ścisłych ${ }^{5}$.

Doktorat stanowi pierwszy szczebel akademicki. I mimo że mamy do czynienia z inflacją stopnia naukowego doktora (odnosi się to do wyższych standardów akademickich i większej selektywności systemu edukacyjnego jeszcze kilka dekad temu oraz egalitaryzacji szkolnictwa wyższego i tym samym rosnącej popularności oraz coraz większego dostępu do studiów III stopnia - co można zaobserwować współcześnie ${ }^{6}$ ), to jednak obrona doktorska i rytuały związane $\mathrm{z}$ nadaniem tego stopnia pozostają na zawsze $\mathrm{w}$ pamięci naukowców, tymbardziej że obrona ma charakter publiczny z udziałem rodzin,

\footnotetext{
${ }^{1}$ J. Verger, Doctor, doctoratus, [w:] Lexikon des Mittelalters, 3, Stuttgart 1999, s. 1155-1156.

2 Tamże.

${ }^{3}$ J. Verger, Licentia, [w:] Lexikon des Mittelalters, s. 1957-1958.

${ }^{4}$ S. Delamont, P. Atkinson, O. Parry, Supervising the Ph.D.: A guide to success, Buckingham 1997.

${ }^{5}$ S. Chang, Academic Genealogy of Mathematicians, World Scientific, 2010, s. 183.

${ }^{6}$ A. Zander, With "Academic degree Inflation", is it time for universities to award academic degree beyond PhD?, źródło: https://www.quora.com/With-Academic-degree-Inflation-is-it-time-for-universities-to-award-academic-degree-beyond-PhD, [dostęp: 15.06.2018]; Z. Melosik, Uniwersytet i spoteczeństwo. Dyskursy wolności, wiedzy i władzy, Kraków 2009, s. 116.
} 
a samo uzyskanie tytułu doktora otwiera możliwość dalszej kariery akademickiej ${ }^{7}$. Nie bez przyczyny w środowisku akademickim świętuje się w sposób niezwykle uroczysty 50. rocznicę uzyskania stopnia naukowego doktora, nazwaną uroczystością odnowienia doktoratu.

Przyznawanie stopni i tytułów naukowych wiąże się niejednokrotnie z tradycją uczelni oraz spójną w swej strukturze ceremonią, podczas której mają miejsce określone rytuały bądź obrzędy, charakterystyczne dla danego uniwersytetu, szkoły wyższej, czy nawet kierunku studiów (niezwykłą rangą i wyjątkowością - biorąc pod uwagę charakter i przebieg wydarzenia - wyróżnia się również uroczystość nadania doktoratu honorowego - doctor honoris causa, przyznawanego za szczególne osiągnięcia naukowe, ale również za znaczący wkład jednostki w życie społeczne i uniwersyteckie). Kolory, przedmioty i symbole mocno zakorzenione $\mathrm{w}$ środowisku akademickim, są niezwykle ważne i widoczne, między innymi właśnie w sytuacji wręczenia dyplomu oraz nadawania stopni akademickich i naukowych. W niniejszym artykule skupię się na rytuałach przejścia związanych z promocją doktorską i charakterystyczną dla tego wydarzenia ceremonią. Podejmę próbę rekonstrukcji tych rytuałów w odniesieniu do uniwersytetów, w których mają one jak najbardziej sztywny i konserwatywny charakter usposabiając wielowiekową tradycję, a złamanie jakiejkolwiek reguły jest niemożliwe. Przed przedstawieniem charakterystyki poszczególnych zwyczajów i zasad obowiązujących podczas ceremonii wręczenia dyplomów, nie sposób nie wspomnieć, czym w istocie jest ceremonia.

Termin „ceremonia” należy do obszaru nauk o kulturze. Jest to wydarzenie o charakterze rytualnym, zorganizowane na rzecz wyjątkowej okazji ${ }^{8}$. Warto wspomnieć, iż rytuały i związane z nimi ceremonie - narodzin, śmierci, małżeństwa, inicjacji, uzdrowienia, lub o charakterze religijnym - występują niemal we wszystkich kulturach i bywa, iż są wykonywane przez dziesiątki tysięcy lat. Ujawniają drogie dla społeczeństwa wartości i niejednokrotnie wywołują emocje (związane jest to z obecnością konkretnych symboli, które oprócz tego, iż wyzwalają emocje, stanowią formę reprezentującą daną grupę społeczną i charakterystyczne dla niej wartości $\left.{ }^{9}\right)$. Biorąc pod uwagę fakt, iż ich warstwa ekspresyjna jest konwencjonalna ${ }^{10}$, a sama ceremonia ma charakter obowiązkowy, wyda-

${ }^{7}$ G.E. Walker i in., The formation of Scholars. Rethinking Doctoral Education for the Twenty-First Century, Stanford 2008, s. 16.

${ }^{8}$ L. Grimes Ronald, Ritual, [w:] Guide to the study of religion, red. W. Braun, Continuum International Publishing Group, 2000, s. 260.

${ }_{9}$ K. Allan, Contemporary Social E Sociological Theory. Visualising Social Worlds, Third Edition, USA 2013, s. 125.

${ }^{10}$ C. Bell, Rithual theory, ritual practice, New York - Oxford 1992, s. 19. 
rzenia tego typu sprzyjają poczuciu solidarności i stanowią nieodłączny element rzeczywistości społecznej ${ }^{11}$.Warto $\mathrm{w}$ tym miejscu poczynić uwagę, iż według Emila Durkheima solidarność grupowa stanowi między innymi poziom integracji społecznej, który może być mierzony poprzez indywidualne poczucie związane z byciem częścią grupy oraz koniecznością działania na rzecz jej dobra ${ }^{12}$. Nieco inną perspektywę myślową ukazuje sposób narracji prezentowany przez Kennetha Allana, który odnosi solidarność grupową do poczucia wspólnotowości i przekonania, że jest się elementem większej zbiorowości. Istotny jest tutaj wymiar emocjonalny - im większe poczucie emocjonalnej przynależności, tym większy sens przynależności do grupy ${ }^{13}$. Tak rozumiana ceremonia ma swoje odzwierciedlenie oraz jest paralelna do wielu innych kontekstów i wymiarów życia społecznego, gdzie bezwzględne przestrzeganie obowiązujących zasad i akceptacja tradycyjnych zaleceń, obrzędów i rytuałów staje się nieodłącznym elementem wpisującym się w logikę określonej rzeczywistości społeczno-kulturowej. Przykładem mogą być ceremonialne praktyki sądowe, które ze względu na swoją przejrzystość, bezwzględność i nieodwołalność przyczyniają się do kształtowania profesjonalnego wizerunku instytucji sądowych, a wszelkie kwestie proceduralne obecne $w$ tej przestrzeni społecznej sprzyjają poszanowaniu praworządności i pozytywnej ocenie całego procesu sądowego. Można zatem zastanowić się nad kwestią, czy ceremonialne praktyki obecne w środowisku akademickim w podobny sposób nie mają za zadanie wpłynąć na pozytywną ocenę ukończonej uczelni, jak również zwiększyć satysfakcję absolwentów z powodu ukończenia studiów oraz podnieść społeczną i utylitarną rangę tytułu lub stopnia, który uzyskaliśmy w toku edukacji, czy też $\mathrm{w}$ trakcie pokonywania kolejnych szczebli kariery naukowej.

Uważa się, iż ceremonia stanowi skrajnie skonwencjonalizowany rytuał bądź obrzęd. Zgodnie z definicją zamieszczoną w Stowniku języka polskiego $P W N$ uważa się, iż jest to "oficjalna uroczystość lub obrzęd przebiegająca według ustalonego planu lub rytuału". Ponadto, zwraca się uwagę, iż jest to „,zynność wykonywana z powagą i dbałością o zachowanie konwenansów"14. W trakcie przebiegu ceremonii, najważniejsza wydaje się warstwa performatywna. Istotne znaczenie mają gesty, słowa, symbole, wygląd uczestników, oprawa, dekoracja i zachowanie osób biorących udział w tym wydarzeniu. Rozbudowana warstwa symboliczna pozwala na określenie, zdefiniowanie i jednoznaczne wyodrębnienie danej społeczności. Służy ona identyfikacji da-

\footnotetext{
11 V. Turner, The ritual process: structure and anti-structure, New York 1991.

12 E. Durkheim, The division of labor in socjety, New York (1893) 1984, s. 11-29.

${ }^{13}$ K. Allan, Contemporary Social, s. 125.

${ }^{14}$ Stownik języka polskiego PWN, red. L. Drabik, E. Sobol, Warszawa 2018.
} 
nej grupy oraz ma swój udział w kreowaniu tożsamości indywidualnej i zbiorowej ${ }^{15}$. Przykładem może być charakterystyczna dla kultury europejskiej ceremonia absolutorium, która w sposób symboliczny kończy okres studiów. Wywodzi się z obrzędów przejścia (tzw. rites de passage ${ }^{16}$ ), stanowiących rodzaj ceremonii, która ma miejsce, kiedy osoba opuszcza jedną grupę i zostaje przyjęta do innej społeczności. Związana jest ona nierozerwalnie ze znaczącą zmianą statusu w społeczeństwie ${ }^{17}$.

Powracając do zagadnienia ceremonii związanej z nadaniem stopnia doktora, należy wspomnieć, że w Stanach Zjednoczonych od 1959 roku istnieje Komitet ds. kostiumów i ceremonii akademickich (the Committee on Academic Costumes and Ceremonies), mianowany przez amerykańską Radę ds. Eduka$\mathrm{cji}^{18}$, natomiast w 1895 roku w Stanach Zjednoczonych powstał akademicki kodeks kostiumowy, który znajduje odzwierciedlenie w większości obecnie noszonych regali - zawiera konkretne zalecenia i sugestie dotyczące akademickiego dress codu (ze szczególnym uwzględnieniem kolorów i materiałów, z jakich wykonane są poszczególne elementy stroju absolwenta) i przebiegu ceremonii. Należy zwrócić uwagę, iż uniwersytety europejskie w większości zachowały swoje prawo do różnorodności ${ }^{19}$, co przejawia się w możliwości na przykład dostosowywania tradycyjnych - sięgających czasów średniowiecza - zwyczajów i symboli do czasów współczesnych, specyfiki danej instytucji oraz zakłada ich nieznaczną modyfikację. Uczelnie tego typu stanowią egzemplifikację bardziej liberalnego podejścia do ceremonii, rytuałów i obrzędów akademickich, dlatego w niniejszym artykule skupię się tylko na wybranych przykładach ukazujących bardziej tradycyjne i konserwatywne podejście do ceremonii oraz regali uniwersyteckich.

Podejmując temat promocji doktorskich, wyróżnić można dwie zasadnicze kwestie, jak: strój (i jego charakterystyczne elementy - biret, kaptur i toga) oraz samą ceremonię.

Wyjdę od stwierdzenia, iż strój akademicki stanowi obowiązkowy element wszystkich oficjalnych ceremonii uniwersyteckich. Kiedyś noszony codziennie, obecnie raczej przeznaczony głównie na ważne wydarzenia uniwersyteckie, między innymi podczas ceremonii wręczania dyplomów i promocji

${ }^{15}$ K. Allan, Contemporary Social, s. 125.

${ }^{16}$ Termin wywodzący się z języka francuskiego. Jako jeden z pierwszych użył go Arnold van Gennep w swojej książce Les rites de passage (The Rites of Passage).

17 A. Van Gennep, Les rites de passage, Paris 1909; Émile Nourry. Lay summary - Review by Frederick Starr, The American Journal of Sociology, 1910, 15, 5, s. 707-709.

${ }_{18}$ Academic Regalia, Academic Ceremony Guide, American Council on Education, źródło: http:/ / www.acenet.edu/news-room/Pages/Academic-Ceremony-Guide.aspx, [dostęp: 15.06.2018].

${ }^{19}$ Hooding: What is it and why do we do it?, źródło: https:/ / www.salisbury.edu/ socialwork/ Program\%20Information_Applications/Hooding-What\%20is\%20it.pdf, [dostęp: 15.06.2018]. 
akademickich ${ }^{20}$. Stylistyka szat akademickich sięga czasów średniowiecznej Europy (XII, XIII w. ${ }^{21}$ ), kiedy stroje te wyznaczały i podkreślały prestiż, rangę oraz zawód osoby je noszącej. Zwyczajowy strój uczonego - zarówno ucznia czy nauczyciela - był strojem kleryka ${ }^{22}$. Stroje akademickie, jakie można współcześnie znaleźć na większości uniwersytetów w Stanach Zjednoczonych, wywodzą się z uniwersytetów w Oksfordzie i Cambridge, stanowiąc kontynuację i/lub następstwo strojów akademickich i duchownych na średniowiecznych uniwersytetach w Europie ${ }^{23}$.

Na przykład, toga noszona obecnie w Oxfordzie jest bardzo podobna do noszonej w średniowieczu. Ostatnie główne modyfikacje miały miejsce w XVI wieku. Warto wspomnieć, iż starsze formy strojów akademickich przyjmują kolory, które były łatwo dostępne w przeszłości, jak niebieski, czerwony lub żółty, obok czerni, koloru fioletowego i bieli. Przykładem może być niebiesko-czarna toga dla osób ze stopniem Doctor of Education na Uniwersytecie Columbia oraz granatowo-czerwona toga dla Doctor of Philosophy na uniwersytecie w Oxfordzie. Absolwenci różnych uniwersytetów noszą togi odpowiadające stopniom i tytułom, które są im przyznawane. W zależności od ukończonego poziomu studiów (licencjat, magisterium, studia doktoranckie), różnią się one na przykład długością i kształtem rękawów (w przypadku absolwentów studiów licencjackich są one krótsze niż te w stroju dla absolwentów studiów magisterskich - w togach przeznaczonych dla drugiej grupy sięgają one poniżej kolan) ${ }^{24}$. Z kolei, dla absolwentów studiów doktoranckich mają one kształt dzwonu i są nieco krótsze - przykładem może być Temple University w Stanach Zjednoczonych ${ }^{25}$. Innym, charakterystycznym elementem stroju absolwenta studiów doktoranckich, znajdującym się na todze, są niekiedy trzy aksamitne pasy widniejące na rękawach ${ }^{26}$.

Na wielu uniwersytetach zachodnich istnieje zasada, iż biret należy nosić $\mathrm{w}$ trakcie procesji akademickiej oraz podczas ceremonii nadania stopni i tytułów naukowych. Mężczyźni mogą zdjąć nakrycie głowy podczas modlitwy, śpiewania hymnu narodowego i Alma Mater, a także niekiedy w innym -

${ }^{20}$ The Burgon Society, źródto: http://www.burgon.org.uk/society/index.php, [dostęp: 15.06.2018].

${ }^{21}$ Academic Regalia Inter-Collegiate Colors, AN ACADEMIC COSTUME CODE AND AN ACADEMIC CEREMONY GUIDE, źródło: https://www.graduationgown.com/academic-code. html, [dostęp: 15.06.2018].

${ }^{22}$ Tamże.

${ }^{23}$ P. Goff, University of London Academic Dress, The Origins of University Costume, źródło: https://web.archive.org/web/20110515070306/http://www.phildress.co.uk/london/origins.html, [dostęp: 15.06.2018].

${ }^{24}$ Cap and Gown 101: Wearing Your Academic Regalia, https://www.youtube.com/ watch?v=J79-VD3dBMY, [dostęp: 15.06.2018].

${ }^{25}$ Tamże.

${ }^{26}$ Tamże. 
ściśle określonym - czasie. Przyjmuje się, że plan każdej uroczystości winien być odpowiednio wcześniej starannie przygotowany, a uczestnicy wydarzenia dokładnie poinstruowani, w którym momencie powinni, a w którym bezwzględnie nie mogą zdjąć nakrycia głowy. Ciekawym, często spotykanym zwyczajem (praktykowanym np. w przywoływanym już Temple University ${ }^{27}$ ) jest zmiana położenia frędzla (tassel) przy birecie. Przyjmuje się, iż na początku uroczystości winien on znajdować się z przodu po prawej stronie, jednak $\mathrm{w}$ momencie nadania stopnia ma miejsce jego symboliczne przełożenie - z prawej na lewą stronę ${ }^{28}$.

Z kolei, spotykane często podczas ceremonii na zachodnich uniwersytetach kaptury również różnią się długością, zależnie od przyznawanego stopnia czy tytułu naukowego. Ich długość średnio zwiększa się o 0,5 stopy $\mathrm{w}$ miarę pokonywania kolejnych szczebli uniwersyteckich (od długości równej 3 stopy w przypadku absolwentów studiów licencjackich do długości równej 4 stopy w przypadku absolwentów studiów doktoranckich ${ }^{29}$. Absolwent, który posiada więcej niż jeden tytuł lub stopień naukowy, może nosić tylko jeden kaptur naraz, w zależności od sytuacji społecznej czy akademickiej, w jakiej się znajduje.

Nałożenie kapturów stanowi istotny element ceremonii akademickich w Stanach Zjednoczonych. Przygotowanie absolwentów do tego momentu - promocji akademickich - jest bardzo szczegółowe, co można dostrzec na ilustrujących to filmach ${ }^{30}$. Z łatwością można dotrzeć do kilkudziesięciu nagrań, które mają na celu przygotować absolwentów do tego momentu w czasie trwania promocji akademickich. Wyróżniamy kilkanaście różnych kolorów kapturów. Kolor zależy od ukończonego kierunku, uzyskanego stopnia oraz uczelni i kraju. W Stanach Zjednoczonych na przykład kolor biały został przydzielony do sztuki, zielony - do medycyny, czerwony - do teologii, oliwkowy - do farmacji, a żółty (w odcieniu złota) przydzielono naukom ścisłym.

\section{Tamże.}

${ }^{28}$ Academic Regalia, Academic Ceremony Guide, American Council on Education, http:// www.acenet.edu/news-room/Pages/Academic-Ceremony-Guide.aspx, [dostęp: 15.06.2018]

${ }_{29}$ Cap and Gown 101: Wearing Your Academic Regalia, źródło: https://www.youtube.com/ watch?v=J79-VD3dBMY, [dostęp: 15.06.2018]; An Academic Costume Code and An Ceremony Guide, źródło: http://correctoncampus.com/wp-content/uploads/2017/03/Academic-Costume-Code-and-An-Ceremony-Guide.pdf, [dostęp: 15.06.2018].

${ }^{30}$ Miami University - Guide to the Doctoral Hooding Ceremony, źródło: https://www.youtube.com/watch?v=9RW3TzW16iE, [dostęp: 15.06.2018]; Proper Hooding Technique for Doctoral Students, https://www.youtube.com/watch?v=VArS2miKy9M, [dostęp, 15.06.2018], Regalia 101 for doctoral degree candidates, źródło: https://www.youtube.com/watch?v=PJeta8-PaTI, [dostęp, 15.06.2018]; Cap and Gown 101: Wearing Your Academic Regalia, https://www.youtube.com/watch?v=J79-VD3dBMY, [dostęp: 15.06.2018], How to Wear a Doctoral Hood, https:/ / www.youtube.com/watch?v=fry4e21uNzo, [dostęp: 15.06.2018], Graduate \& Doctoral Hooding, https:/ / www.youtube.com/watch?v=uK-FzTIRc9I, [dostęp: 15.06.2018]. 
Dla stopnia doktora charakterystyczny kolor to ciemnoniebieski ${ }^{31}$. Użycie tego koloru zostało wyjaśnione w kolejnej aktualizacji kodów kostiumowych dokonanej przez Komitet ds. Kostiumów i Ceremonii Akademickich (A Committee on Academic Costumes and Ceremonies) w roku $1986^{32}$. Wnętrze kapturów ozdobione jest barwami szkoły wyższej - uczelni, która nadaje tytuł lub stopień naukowy ${ }^{33}$.

Ceremonie zakapturzenia (Hooding Ceremonies) są przeprowadzane przez instytucje szkolnictwa wyższego, aby wyróżnić i zaprezentować studentów, którzy uzyskali wyższy stopień wykształcenia (np. ukończyli studia magisterskie lub studia doktorskie). Podczas ceremonii każdy absolwent podchodzi, wyczytuje się jego imię, po czym zostaje mu założony kaptur (o określonym kolorze) przez osobę stojącą na czele wydziału - rektora lub dziekana. Jest to szczególna część akademickich regaliów potwierdzająca zdobyte osiągnięcia naukowe i zawodowe ${ }^{34}$. W naszym kraju nie bywa to praktykowane, jednak na przykład w Stanach Zjednoczonych ceremonie tego typu mają długą tradycję, a sam fakt nałożenia kaptura stanowi - jak już pisano - niejednokrotnie obowiązkowy element uroczystości nadawania kolejnych stopni i tytułów naukowych. Tradycyjna zasada głosi, że absolwent nie powinien nosić kaptura danego stopnia, dopóki nie zostanie on jemu faktycznie przyznany. Niekiedy, w sytuacji gdy absolwenci stanowią liczną grupę osób, rezygnuje się wówczas z indywidualnego nałożenia kapturów (najprawdopodobniej ze względów logistycznych i czasowych) - jest to jedyna sytuacja, kiedy kandydaci na wyższe stopnie uniwersyteckie mogą mieć na sobie swoje kaptury - zarówno w czasie procesji wstępnej, jak i podczas głównej części ceremonii ${ }^{35}$.

Z dokumentu odnoszącego się do promocji akademickich na przywoływanym już uniwersytecie w Oxfordzie dowiadujemy się, iż ceremonia na tym uniwersytecie zachowuje wszystkie niezbędne elementy, zgodnie z obowiązującymi w pierwszych latach ich praktykowania (druga połowa XII wieku), w tym również fakt, iż odbywa się ona po łacinie. Uczestnicy noszą pełne stroje akademickie, odpowiednie do ich obecnego statusu na uniwersytecie. Kandydaci siedzą, zgodnie z kolejnością ich prezentacji

${ }^{31}$ An Academic Costume Code and An Ceremony Guide, http://correctoncampus.com/ wp-content/uploads/2017/03/Academic-Costume-Code-and-An-Ceremony-Guide.pdf, [dostęp: 15.06.2018].

${ }^{32}$ Academic Regalia Inter-Collegiate Colors, AN ACADEMIC COSTUME CODE AND AN ACADEMIC CEREMONY GUIDE, źródło: https://www.graduationgown.com/academic-code. html, [dostęp: 15.06.2018].

${ }^{33}$ Tamże.

${ }^{34}$ Hooding: What is it and why do we do it?, źródło: https:/ / www.salisbury.edu/ socialwork/ Program\%20Information_Applications/Hooding-What\%20is\%20it.pdf, [dostęp: 15.06.2018].

${ }_{35}$ Academic Regalia, Academic Ceremony Guide, American Council on Education, źródło: http:/ / www.acenet.edu/news-room/Pages/Academic-Ceremony-Guide.aspx, [dostęp: 15.06.2018]. 
(najczęściej po obu stronach sali). Przed nimi znajdują się rektor, dziekani i profesorowie uczelni. Ceremonia rozpoczyna się po angielsku, a następnie postępowanie zostaje otwarte formułą łacińską. Na uniwersytecie w Oxfordzie brzmi ona następująco ${ }^{36}$ :

Causa huius Congregationis est ut Gratiae concedantur, ut gradus conferantur, necnon ut alia peragantur, quae ad hanc Venerabilem Domum spectant (Powodem tego zgromadzenia jest to, że łaski są dane i mamy możliwość przyznawania stopni, jak również dokonania innych rzeczy w tym Czcigodnym Domu) ${ }^{37}$.

Następnie sekretarz lub zastępca oświadcza, że wszyscy kandydaci otrzymali zgodę na przyznanie im stopni i tytułów naukowych, a ich kwalifikacje zostały zweryfikowane.

Ego Registraria Adjutrix testor omnibus candidatis, quorum nomina vel Venerabili Domui a Procuratoribus statim submittentur vel in schedulis a Registraria rite publicata erant, gratias a Collegiis vel Societatibus suis pro gradibus quaesitis concessas fuisse, et easdem mihi satisfecisse (Ja, Sekretarz, zaświadczam, że wszyscy kandydaci (których biorę na świadków), i których imiona będą natychmiast przesłane do Czcigodnego Domu przez Proctorów [osoby nadzorujące przebieg wydarzenia - E.S.] lub będą opublikowane przez Sekretarza, otrzymują zgodę na przyznanie im stopni naukowych łaską ich uczelni lub towarzystwa dla wymaganych stopni oraz oświadczam, iż osoby te spełniają wszystkie wymagania) $)^{38}$.

W dalszej kolejności ma miejsce tradycyjne - aby użyć dosłownego tłumaczenia z tekstów poświęconych tej tematyce - „błaganie” (supplication) o wyższe stopnie naukowe. Proctorzy powstają, a starszy Proctor czyta nazwiska kandydatów, którzy „błagają” o przyznanie im wyższych stopni, wygłaszając następującą formułę:

Supplicant venerabili Congregationi Doctorum et Magistrorum regentium A, B, C, D, e Collegio $E$, qui compleverunt omnia quae per Statuta requiruntur (nisi quatenus cum eo dispensatum fuerit); ut haec sufficiant, quo admittantur ad Gradum enumeratum. (A, B, C, D, z Uniwersytetu E, który spełniłeś wszystkie zalecenia, które są wymagane przez statut (za wyjątkiem przypadków, w którym została przyznana dyspensa), zapytaj Czcigodną Kongregację i Mistrzów, czy te rzeczy wystarczą, aby zostać przyjętym na następujący stopień).

Kiedy prośby zostały przeczytane, Proctorzy przechodzą przed Dziekanami w jedną i w drugą stronę. Zachowanie przez wszystkich milczenia wskazuje na akceptację próśb kandydatów. Przyjmuje się, iż jest to zwyczajowy sposób

${ }^{36}$ Degree Ceremony. University of Oxford, źródło: https://www.ox.ac.uk/media/global/wwwoxacuk/localsites/studentgateway/documents/Degree_Ceremony_Brochure.pdf, [dostęp: 15.06.2018].

37 Tamże.

38 Tamże. 
głosowania na uniwersytecie, stanowiący możliwość publicznego wyrażenia sprzeciwu wobec konkretnej kandydatury. Po głosowaniu Proctorzy wracają na swoje miejsca, po czym Starszy Proctor ogłasza, iż stopnie zostają przyznane, wygłaszając po raz kolejny stosowną formułę w języku łacińskim ${ }^{39}$.

Ceremonia nadania stopni i tytułów naukowych składa się z kilku następujących po sobie części, uwzględniających wszystkie wymienione wcześniej elementy i zasady związane z promocją doktorską. Zazwyczaj jest to wydarzenie - a odnosi się to przede wszystkim do Stanów Zjednoczonych - dzielące się na następujące etapy zgodnie z zaleceniami i zasadami ustalonymi między innymi przez American Council on Education: Procesja Wstępna (The Preliminary Procession), Ceremonia Rozpoczęcia (The Commencement Ceremony) i Kolejna Procesja (The Subsequent Procession).

W skład Procesji Wstępnej wchodzi kilka grup: mówcy, członkowie zarządu, pracownicy administracyjni oraz inni członkowie zasiadający na platformie (niekiedy, zgodnie ze zwyczajami obowiązującymi na uczelni, może ona być powiększona o grupę dostojników kościelnych - osoby te zajmują tradycyjne miejsca w procesji, określone przez daną instytucję); społeczność Wydziału oraz kandydaci na stopnie naukowe, kandydaci na wyższe stopnie i wszyscy inni kandydaci według stopni, do których są kandydatami. Mogą oni wchodzić na salę według powyższej kolejności lub w porządku odwrotnym. W przypadku tej drugiej opcji, kandydaci, którzy podczas niniejszej uroczystości odbiorą dyplomy, po odnalezieniu swoich miejsc zobowiązani są na znak szacunku zwrócić swoje głowy w kierunku przejścia, po którym będą poruszać się pozostałe grupy biorące udział w ceremonii.

Z kolei następuje Ceremonia Rozpoczęcia (The Commencement Ceremony). Jej najważniejszym punktem jest przyznawanie stopni i tytułów naukowych. Odbywa się to w kolejności od stopnia najniższego do najwyższego. Niekiedy zdarza się, że kolejność jest odwrócona - na przykład stopnie i tytuły nadawane są począwszy od absolwentów studiów doktoranckich po absolwentów studiów licencjackich.

Podczas Kolejnej Procesji (The Subsequent Procession) osoby zasiadające na platformie oraz społeczność Wydziału opuszczają miejsce, w którym odbywa się ceremonia. Absolwenci poszczególnych etapów studiów mogą być poproszeni o dołączenie do procesji lub opuszczenie swoich siedzeń w momencie, kiedy pozostali uczestnicy wydarzenia wyjdą z sali ${ }^{40}$.

Akademickie regalia, symbole, obrzędy i ceremonie stanowią ważny element rzeczywistości uniwersyteckiej. Siłą rządzącą jest tutaj tradycja i ciągłość zachowania symboli, które obowiązują już od czasów średniowiecza.

39 Tamże.

40 An Academic Costume Code and An Ceremony Guide, źródło: http://correctoncampus. com/wp-content/uploads/2017/03/Academic-Costume-Code-and-An-Ceremony-Guide.pdf, [dostęp, 15.06.2018]. 
Niekiedy dopuszcza się indywidualne zmiany i modyfikacje dokonane przez poszczególne uniwersytety do warunków lokalnych (jak ma to miejsce w krajach europejskich), jednak jest to możliwe jedynie wówczas, kiedy są one uzasadnione i wierne duchowi tradycji ${ }^{41}$.

Niniejsze argumenty wskazują na wielowymiarowość samego pojęcia, jak i związanego z nim wyjątkowego wydarzenia, które mieści się w słowie "ceremonia", oznaczającym - jak już zostało to wspomniane - skonwencjonalizowany rytuał. Bezsprzecznie stanowi ona przykład oraz swoiste potwierdzenie niezwykłej rangi i doniosłości danego momentu oraz podkreśla wyjątkowość tejże sytuacjii ${ }^{42}$, która nie może obyć się bez egzekwowania znajomości rytuałów, symboli oraz poprawnego ich odczytywania i stosowania. W sposób szczególny ranga i specyfika wydarzeń o takim charakterze widoczna jest podczas sytuacji związanej z nadawaniem stopni i tytułów naukowych, czego przykładem jest omawiane w tym tekście wręczenie dyplomów po obronie pracy doktorskiej. Bez wątpienia, promocje doktorskie na długo pozostają $\mathrm{w}$ pamięci naukowców oraz można uznać je za pierwszy przystanek na drodze do dalszej kariery naukowej oraz do pełnej wolności akademickiej. Stanowią one symboliczne przejście z rzeczywistości naukowej, prowadzonej i kreowanej w dużym stopniu przez promotora dysertacji doktorskiej, do czasów samodzielnego myślenia i w pełni odpowiedzialnego tworzenia (poprzez np. samodzielne wybranie przedmiotu badań oraz prezentowanie wyników i wniosków z prowadzonych analiz, po nauczanie studentów oraz wyrażanie indywidualnych, pełnoprawnych opinii i refleksji ${ }^{43}$ ) swojej naukowej biografii przez osobę, która pozytywnie ukończyła okres studiów doktoranckich, obroniła pracę doktorską oraz uzyskała miano doktora w określonej dziedzinie studiów i obszarze wiedzy.

Ceremonie te wpisują się więc w uzyskanie przez nowego doktora większego zakresu wolności akademickiej, która jak pisze L. Menand:

nie jest rodzajem „premii” dla pracowników systemu, luksusem filozoficznym. Uniwersytety mogłyby funkcjonować bez niej równie efektywnie i na pewno znacznie wydajnej. Stanowi ona [jednak - E.S.] pojęcie fundamentalne, uprawomocniające całe przedsięwzięcie ${ }^{44}$.

Jednocześnie odnosi się do

${ }^{41}$ Tamże.

${ }^{42}$ J. Tinson, P. Nuttall, Exploring appropration of global cultural rituals, [w:] Multicultural Perspectives in Customer Behaviour, red. M.G. Piacentini, Ch.C. Cui, New York 2012, s. 81.

${ }^{43}$ Z. Melosik, Uniwersytet $i$ społeczeństwo, s. 11-12.

${ }^{44}$ L. Menand, The Limits of Academic Freedom, [w:] The Future of Academic Freedom, red. L. Menand, Chicago - London 1996, s. 4. Podaję za: Z. Melosik, Uniwersytet i społeczeństwo, s. 11. 
wolności w zakresie poszukiwania i zrozumienia prawdy, pogłębiania przedmiotu swoich zainteresowań, twórczego poszukiwania różnych możliwości rozwiązywania problemów [oraz - E.S.] komunikowania wyników innym osobom ${ }^{45}$.

Uważam zatem, że ceremonie akademickie, a w sposób szczególny promocje doktorskie, stają się - w sposób symboliczny - uosobieniem tej rosnącej uniwersyteckiej wolności i stanowią swoisty „rytuał przejścia” w kierunku prawdziwej, indywidualnej i w pełni odpowiedzialnej drogi edukacyjnej, a wszystko w trosce o prawdziwą naukową wolność oraz w imię walki o akademicką przyszłość uniwersytetu.

\section{BIBLIOGRAFIA}

Academic Regalia, Academic Ceremony Guide, American Council on Education, źródło: http:/ / www.acenet.edu/news-room/Pages/Academic-Ceremony-Guide.aspx, [dostęp: 15.06.2018].

Academic Regalia Inter-Collegiate Colors, AN ACADEMIC COSTUME CODE AND AN ACADEMIC CEREMONY GUIDE, źródło: https://www.graduationgown.com/academiccode.html, [dostęp: 15.06.2018].

An Academic Costume Code and An Ceremony Guide, źródło: http:/ / correctoncampus.com/ wp-content/uploads/2017/03/Academic-Costume-Code-and-An-Ceremony-Guide. pdf, [dostęp: 15.06.2018].

Allan K., Contemporary Social \& Sociological Theory. Visualising Social Worlds, Third Edition, Sage, USA 2013.

Bell C., Rithual theory, ritual practice, Oxford University Press, New York - Oxford 1992.

Cap and Gown 101: Wearing Your Academic Regalia, https:/ / www.youtube.com/watch?v=J79-VD3dBMY, [dostęp: 15.06.2018].

Chang S., Academic Genealogy of Mathematicians, World Scientific, 2010.

Degree Ceremony. University of Oxford, źródło: https://www.ox.ac.uk/media/global/ wwwoxacuk/localsites/studentgateway/documents/Degree_Ceremony_Brochure. pdf, [dostęp: 15.06.2018].

Delamont S., Atkinson P., Parry O., Supervising the Ph.D.: A guide to success, Open University Press, Buckingham 1997.

Dorleijn G.J., Vanstiphout H.L.J.(Eds.), Cultural Repertoires. Structure, Function, Dynamics, Petters, Leuven - Paris - Dudley - MA 2003.

Durkheim E., The division of labor in socjety, The Free Press, New York (1893) 1984.

Émile Nourry. Lay summary - Review by Frederick Starr, The American Journal of Sociology, 1910, 15, 5.

Goff P., University of London Academic Dress, The Origins of University Costume, źródło: https://web.archive.org/web/20110515070306/http://www.phildress.co.uk/london/ origins.html, [dostęp: 15.06.2018].

Graduate E Doctoral Hooding, https:/ / www.youtube.com/watch?v=uK-FzTIRc9I, [dostęp: 15.06.2018].

${ }^{45}$ M. Tight, So, What Is Academic Freedom, [w:] The Future of Academic freedom, red. L. Menand, Chicago - London 1996, s. 116-117. Podaję za: Z. Melosik, Uniwersytet i społeczeństwo, s. 13-14. 
Grimes R.L., Ritual, [w:] Guide to the study of religion, red. Willi Braun, Russell T. McCutcheon, Continuum International Publishing Group, 2000.

Hooding: What is it and why do we do it?, źródło: https:/ / www.salisbury.edu/socialwork/ Program \%20Information_Applications/Hooding-What\%20is\%20it.pdf, [dostęp: 15.06.2018].

How to Wear a Doctoral Hood, https:/ / www.youtube.com/watch?v=fry4e21uNzo, [dostęp: 15.06.2018],

Melosik Z., Uniwersytet i społeczeństwo. Dyskursy wolności, wiedzy i władzy, Oficyna Wydawnicza Impuls, Kraków 2009.

Menand L., The Limits of Academic Freedom, [w:] The Future of Academic Freedom, red. L. Menand, Chicago - London 1996.

Miami University - Guide to the Doctoral Hooding Ceremony, źródło: https:/ / www.youtube. com/watch?v=9RW3TzW16iE, [dostęp: 15.06.2018].

Moore S.F., Myerhoff B.G., Secular Ritual: Forms and Meanings, [w:] Secular Ritual, red. S.F. Moore, B.G. Myerhoff, Van Gorcum, The Netherlands 1977.

Proper Hooding Technique for Doctoral Students, https:/ / www.youtube.com/watch?v=VArS2miKy9M, [dostęp: 15.06.2018].

Regalia 101 for doctoral degree candidates, źródło: https:/ / www.youtube.com/watch?v=PJeta8-PaTI, [dostęp: 15.06.2018].

Słownik jezzyka polskiego PWN, red. L. Drabik, E. Sobol, Wydawnictwo Naukowe PWN, Warszawa 2018.

Staal F., The Meaninglessness of Ritual, Numen, 1979, 26, 1.

The Burgon Society, źródło: http://www.burgon.org.uk/society/index.php, [dostęp: 15.06.2018].

Tight M., So, What Is Academic Freedom, [w:] The Future of Academic freedom, red. L. Menand, Chicago - London 1996.

Tinson J., Nuttall P., Exploring appropriation of global cultural rituals, [w:] Multicultural Perspectives in Customer Behaviour, red. M.G. Piacentini, Ch.C. Cui, Routledge, New York 2012.

Turner V., The ritual process: structure and anti-structure, ITHACA, New York 1991.

Van Gennep A., Les rites de passage, Paris 1909.

Verger J., Doctor, doctoratus, [w:] Lexikon des Mittelalters, 3, J.B. Metzler, Stuttgart 1999.

Verger J., Licentia, [w:] Lexikon des Mittelalters, 3, J.B. Metzler, Stuttgart 1999.

Walker G.E., Golde C.M., Jones L., Conklin Bueschel A., Hutchings P., The formation of Scholars. Rethinking Doctoral Education for the Twenty-First Century, Carnegie Foundation for the Advancement of Teaching, Jossey Bass, Stanford 2008.

Zander A., With "Academic degree Inflation", is it time for universities to award academic degree beyond PhD?, źródło: https:/ / www.quora.com/With-Academic-degree-Inflation-is-it-time-for-universities-to-award-academic-degree-beyond-PhD, [dostęp: 15.06.2018]. 